\title{
Mature Results of an Individualized Radiation Dose Prescription Study Based on Normal Tissue Constraints in Stages I to III Non-Small-Cell Lung Cancer
}

Citation for published version (APA):

van Baardwijk, A., Wanders, S., Boersma, L., Borger, J., Oellers, M., Dingemans, A-M. C., Bootsma, G., Geraedts, W., Pitz, C., Lunde, R., Lambin, P., \& De Ruysscher, D. (2010). Mature Results of an Individualized Radiation Dose Prescription Study Based on Normal Tissue Constraints in Stages I to III Non-Small-Cell Lung Cancer. Journal of Clinical Oncology, 28(8), 1380-1386.

https://doi.org/10.1200/JCO.2009.24.7221

Document status and date:

Published: 10/03/2010

DOI:

10.1200/JCO.2009.24.7221

Document Version:

Publisher's PDF, also known as Version of record

Document license:

Taverne

Please check the document version of this publication:

- A submitted manuscript is the version of the article upon submission and before peer-review. There can be important differences between the submitted version and the official published version of record. People interested in the research are advised to contact the author for the final version of the publication, or visit the DOI to the publisher's website.

- The final author version and the galley proof are versions of the publication after peer review.

- The final published version features the final layout of the paper including the volume, issue and page numbers.

Link to publication

\footnotetext{
General rights rights.

- You may freely distribute the URL identifying the publication in the public portal. please follow below link for the End User Agreement:

www.umlib.nl/taverne-license

Take down policy

If you believe that this document breaches copyright please contact us at:

repository@maastrichtuniversity.nl

providing details and we will investigate your claim.
}

Copyright and moral rights for the publications made accessible in the public portal are retained by the authors and/or other copyright owners and it is a condition of accessing publications that users recognise and abide by the legal requirements associated with these

- Users may download and print one copy of any publication from the public portal for the purpose of private study or research.

- You may not further distribute the material or use it for any profit-making activity or commercial gain

If the publication is distributed under the terms of Article $25 \mathrm{fa}$ of the Dutch Copyright Act, indicated by the "Taverne" license above, 
From the Department of Radiation Oncology (MAASTRO), GROW Research Institute; Department of Pulmonology, Maastricht University Medical Center, Maastricht; Department of Pulmonology, Atrium Medical Centre, Heerlen; Department of Pulmonology, Orbis Medical Centre, Sittard; Department of Pulmonology, Laurentius Hospital, Roermond; and the Department of Pulmonology, Sint Jans Gasthuis, Weert, the Netherlands.

Submitted June 19, 2009; accepted November 18, 2009; published online ahead of print at www.jco.org on February 8, 2010.

Presented in part at the 13th World Conference on Lung Cancer, July 31-August 4, 2009, San Francisco, CA.

Authors' disclosures of potential conflicts of interest and author contributions are found at the end of this article.

Clinical Trials repository link available on JCO.org.

Corresponding author: Angela van Baardwijk, MD, PhD, Maastricht University Medical Center, Department of Radiation Oncology (MAASTRO), Dr Tanslaan 12, 6229 ET Maastricht, the Netherlands; e-mail: angela.vanbaardwijk@maastro.n (C) 2010 by American Society of Clinical Oncology

0732-183X/10/2808-1380/\$20.00 DOI: 10.1200/JCO.2009.24.722

\section{Mature Results of an Individualized Radiation Dose Prescription Study Based on Normal Tissue Constraints in Stages I to III Non-Small-Cell Lung Cancer}

Angela van Baardwijk, Stofferinus Wanders, Liesbeth Boersma, Jacques Borger, Michel Öllers, Anne-Marie C. Dingemans, Gerben Bootsma, Wiel Geraedts, Cordula Pitz, Ragnar Lunde, Philippe Lambin, and Dirk De Ruysscher

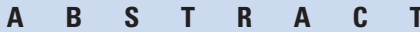

\section{Purpose}

We previously showed that individualized radiation dose escalation based on normal tissue constraints would allow safe administration of high radiation doses with low complication rate. Here, we report the mature results of a prospective, single-arm study that used this individualized tolerable dose approach.

\section{Patients and Methods}

In total, 166 patients with stage III or medically inoperable stage I to II non-small-cell lung cancer, WHO performance status 0 to 2, a forced expiratory volume at 1 second and diffusing capacity of lungs for carbon monoxide $\geq 30 \%$ were included. Patients were irradiated using an individualized prescribed total tumor dose (TTD) based on normal tissue dose constraints (mean lung dose, 19 Gy; maximal spinal cord dose, $54 \mathrm{~Gy}$ ) up to a maximal TTD of 79.2 Gy in 1.8 Gy fractions twice daily. Only sequential chemoradiation was administered. The primary end point was overall survival (OS), and the secondary end point was toxicity according to Common Terminology Criteria of Adverse Events (CTCAE) v3.0.

\section{Results}

The median prescribed TTD was 64.8 Gy (standard deviation, $\pm 11.4 \mathrm{~Gy}$ ) delivered in $25 \pm 5.8$ days. With a median follow-up of 31.6 months, the median OS was 21.0 months with a 1-year OS of $68.7 \%$ and a 2 -year OS of $45.0 \%$. Multivariable analysis showed that only a large gross tumor volume significantly decreased OS $(P<.001)$. Both acute (grade $3,21.1 \%$; grade $4,2.4 \%)$ and late toxicity (grade 3, 4.2\%; grade 4, 1.8\%) were acceptable.

\section{Conclusion}

Individualized prescribed radical radiotherapy based on normal tissue constraints with sequential chemoradiation shows survival rates that come close to results of concurrent chemoradiation schedules, with acceptable acute and late toxicity. A prospective randomized study is warranted to further investigate its efficacy.

\section{J Clin Oncol 28:1380-1386. (C) 2010 by American Society of Clinical Oncology}

\section{INTRODUCTION}

The prognosis for non-small-cell lung cancer (NSCLC) remains poor, even in patients suitable for treatment with curative intent. ${ }^{1}$ Local failure remains an important problem, ${ }^{2}$ resulting in 2-year local tumor control rates as low as $20 \%{ }^{3,4}$ The ability of radiotherapy to achieve local control is mainly hampered by the radiation sensitivity of normal structures, including lungs and spinal cord. Several approaches have been applied to improve local control, including increasing the radiation dose and/or concomitant chemotherapy. ${ }^{5-10}$ Various strategies have been used to escalate radiation dose, such as improving target volume definition and using innovative imaging and treatment delivery techniques, such as four-dimensional computed tomography (4D-CT), positron emission tomography (PET) scans, ${ }^{4,11-13}$ and intensity-modulated radiation therapy (IMRT). ${ }^{11,14-17}$ Dose escalation can be performed by assigning different radiation dose levels to different risk groups. ${ }^{7,9}$ However, we previously demonstrated in a modeling study and a subsequent feasibility trial that high local tumor control rates with low adverse effects could be achieved by individualized radiation dose prescription based on normal tissue dose constraints. ${ }^{16,17}$ Since overall treatment time is of vital importance in 
radiotherapy for NSCLC, ${ }^{4,8,18}$ radiation should preferentially be delivered in $<4$ weeks. The theoretical gain of such a scheme was estimated to be approximately $25 \%$ for tumor control probability compared with the standard schedule of $60 \mathrm{~Gy}$ in 2 Gy fractions in 6 weeks. ${ }^{16}$ Here, we report the mature results of a large prospective study applying this individualized maximal tolerable dose approach.

\section{PATIENTS AND METHODS}

\section{Study Population}

From December 2004 until June 2007, all consecutive eligible patients at MAASTRO Clinic were entered onto this prospective study. Included were those with stage III (except pleural effusion) or medically inoperable stage I to II disease, histologic or cytologic confirmed NSCLC, no prior thoracic radiation, and a workup according to national guidelines. ${ }^{19} \mathrm{~A}$ WHO performance status of 0 to 2 and a weight loss of $<10 \%$ in 6 months were required. All patients had to have a moderate-to-good lung function (a forced expiratory volume in 1 second $\left[\mathrm{FEV}_{1}\right] \geq 30 \%$ of predicted value and a diffusing capacity of lungs for carbon monoxide $\left[\mathrm{DL}_{\mathrm{CO}}\right]$ not corrected for alveolar volume $\geq 30 \%$ ). During the study period, induction chemotherapy was standard of care for patients with $\mathrm{N} 2 / \mathrm{N} 3$ and T4 tumors and consisted of three courses of gemcitabine $\left(1,250 \mathrm{mg} / \mathrm{m}^{2}\right.$ on days 1 and 8$)$ in combination with cisplatin (75 $\mathrm{mg} / \mathrm{m}^{2}$ ) or carboplatin (area under the concentration-time curve [AUC] 5) on day 1. Cycles were repeated every 21 days, and standard dose-reduction rules were applied. An interval between chemotherapy and radiotherapy of at minimum 14 days was mandatory. In this study, no concurrent chemoradiation was given. During the study period, only a limited number of patients who enrolled in another study protocol received concurrent chemoradiotherapy. The study has been approved by the institutional review board and registered in the National Cancer Institute trial database (NCT00573040). Informed consent with regard to treatment was obtained from all patients.

\section{Radiotherapy Treatment Planning}

A PET-CT scan was performed before start of radiation (Biograph, Siemens, Knoxville, TN), and delineation was based on fused PET-CT images as described earlier. ${ }^{17}$ The total gross tumor volume (GTV) consisted of the primary tumor (GTV-1), which is the (postchemotherapy) CT-based volume, and the initially PET-positive lymph nodal areas (GTV-2). ${ }^{20}$ Nodes that proved to be malignant on mediastinoscopy or transesophageal/transbronchial fine-needle aspiration, even if they were PET-negative, were also included in GTV-2. No elective hilar or mediastinal irradiation was carried out. For the clinical target volume (CTV-1 and CTV-2), a margin of $5 \mathrm{~mm}$ around GTV was used. The planning target volume was created by adding a $10-\mathrm{mm}$ margin to CTV-1 and a 5-mm margin to CTV-2. For calculation of the mean lung dose (MLD), the volume of both lungs minus the GTV was considered. ${ }^{20}$ The spinal cord was drawn at the inner margin of the bony spinal canal.

A 3D conformal treatment plan was calculated (XiO, CMS, St Louis, $\mathrm{MO}$ ) according to the International Commission on Radiation Units and Measurements guidelines ${ }^{21}$ using a fast Fourier transform convolution algorithm for inhomogeneity corrections. Patients were irradiated on a linear accelerator (Elekta SL 15, Elekta Oncology Systems, Crawley, United Kingdom or Siemens Oncor, Siemens Medical Solutions, Concord, CA). Treatment verification was performed using electronic portal imaging device measurements. ${ }^{22}$

\section{Treatment}

For all enrolled patients, the following radiation doses were individually escalated until a dose-limiting normal tissue constraint was reached: a maximal MLD between 10.0 and $19.0 \mathrm{~Gy}$ (standard deviation, $\pm 1.0 \mathrm{~Gy}$ ), a maximal dose for the cord of $54.0 \pm 0.5 \mathrm{~Gy}$, maximal dose to great vessels or main bronchi of $70.2 \mathrm{~Gy}$, and maximal dose for the plexus brachialis of 66 Gy. ${ }^{23-27}$ The maximal allowed MLD was dependent on lung function tests: $\mathrm{FEV}_{1}$ and $\mathrm{DL}_{\mathrm{CO}} \geq 50 \%$ and an MLD of $19 \mathrm{~Gy}$ (group 1 ), $\mathrm{FEV}_{1}$ and $\mathrm{DL}_{\mathrm{CO}} \geq$ $40 \%$ and less than $50 \%$ of an MLD of $15 \mathrm{~Gy}$ (group 2), and $\mathrm{FEV}_{1}$ and $\mathrm{DL}_{\mathrm{CO}}$ $\geq 30 \%$ and less than $40 \%$ of an MLD of 10 Gy (group 3). No specific esophageal dose constraint was used because acute esophagitis was not considered to be dose-limiting with radiation alone. ${ }^{17,28}$ The maximal allowed total tumor dose (TTD) was $79.2 \mathrm{~Gy}^{26}$ in twice daily fractions of $1.8 \mathrm{~Gy}$ with an interfraction interval of at least 8 hours. To minimize the effect of accelerated repopulation, a short overall treatment time should be chosen. ${ }^{4,29}$ To achieve this, a twice daily scheme was preferred, since this might spare normal tissues and could allow high-dose irradiation of tumors next to critical organs compared with hypofractionation. ${ }^{16}$ The biologic equivalent dose for tumors in 2 Gy fractions was calculated using the linear quadratic model ${ }^{29-31}$ and corrected for overall treatment time $\left(\mathrm{EQD}_{2, \mathrm{~T}}\right)$ as previously described. ${ }^{16}$

\section{End Points}

The primary end point was overall survival (OS), and the secondary end point was toxicity. Patients were seen before the start of radiotherapy (baseline), weekly during radiotherapy, and regularly afterwards. Survival status was evaluated in February 2009 using the "Gemeentelijke Basis Administratie" system, a decentralized population registration system containing information

\begin{tabular}{|c|c|c|}
\hline Characteristic & No. of Patients & $\%$ \\
\hline \multicolumn{3}{|l|}{ Age, years } \\
\hline Median & \multicolumn{2}{|l|}{69.0} \\
\hline Range & \multicolumn{2}{|l|}{$44-88$} \\
\hline \multicolumn{3}{|l|}{ Sex } \\
\hline Male & 115 & 69 \\
\hline Female & 51 & 31 \\
\hline \multicolumn{3}{|l|}{ WHO PS } \\
\hline 0 & 39 & 23 \\
\hline 1 & 82 & 49 \\
\hline 2 & 28 & 17 \\
\hline 3 & 2 & 1 \\
\hline \multicolumn{3}{|l|}{ Histology } \\
\hline Squamous cell carcinoma & 21 & 13 \\
\hline Adenocarcinoma & 56 & 34 \\
\hline Large cell & 74 & 42 \\
\hline Unknown & 2 & 1 \\
\hline \multicolumn{3}{|l|}{ Clinical stage } \\
\hline 1 & 48 & 29 \\
\hline ॥ & 16 & 10 \\
\hline IIIA & 35 & 21 \\
\hline IIIB & 64 & 38 \\
\hline IV & 3 & 2 \\
\hline \multicolumn{3}{|l|}{ Induction chemotherapy } \\
\hline Yes & 92 & 55 \\
\hline No & 74 & 45 \\
\hline \multicolumn{3}{|l|}{ GTV (tumor load), $\mathrm{mL}$} \\
\hline Median & 50.3 & \\
\hline Range & $1.1-2,286.9$ & \\
\hline \multicolumn{3}{|l|}{ Prescribed TTD, Gy } \\
\hline Median & 64.8 & \\
\hline Range & $50.4-79.2$ & \\
\hline \multicolumn{3}{|c|}{$\mathrm{EQD}_{2, \mathrm{~T}}$ (corrected for proliferation), Gy } \\
\hline Median & 66.0 & \\
\hline Range & $51.9-73.1$ & \\
\hline \multicolumn{3}{|l|}{ MLD, Gy } \\
\hline Median & 14.8 & \\
\hline Range & $2.4-21.7$ & \\
\hline \multicolumn{3}{|l|}{ OTT, days } \\
\hline Median & 25 & \\
\hline Range & $1-50$ & \\
\hline
\end{tabular}

Abbreviations: PS, performance status; GTV, total gross tumor volume; TTD, total tumor dose; $E Q D_{2}$, equivalent dose in 2 Gy fractions corrected for proliferation; MLD, mean lung dose; OTT, overall treatment time. 


\begin{tabular}{|c|c|c|c|c|c|c|c|c|c|c|c|}
\hline \multirow[b]{2}{*}{ Characteristic } & \multirow[b]{2}{*}{ No. } & \multicolumn{3}{|c|}{ Total GTV (mL) } & \multicolumn{3}{|c|}{ TTD (Gy) } & \multirow{2}{*}{$\begin{array}{c}\text { \% Receiving } \\
79.2 \mathrm{~Gy}\end{array}$} & \multicolumn{3}{|c|}{ MLD (Gy) } \\
\hline & & Median & SD & Range & Median & SD & Range & & Median & SD & Range \\
\hline Group 1 (FEV $\left.1-\mathrm{DL}_{\mathrm{CO}} 30 \%-40 \%\right)$ & 25 & 10.8 & 35.8 & $1.1-138.4$ & 79.2 & 10.6 & $50.4-79.2$ & 52.1 & 8.9 & 2.3 & $4.1-12.7$ \\
\hline Group $2\left(\mathrm{FEV}_{1}-\mathrm{DL}_{\mathrm{CO}} 40 \%-50 \%\right)$ & 26 & 49.1 & 123.6 & $1.5-510.2$ & 64.8 & 9.9 & $50.4-79.2$ & 15.4 & 12.3 & 4.1 & $2.4-16.3$ \\
\hline Group $3\left(\mathrm{FEV}_{1}-\mathrm{DL}_{\mathrm{CO}}>50 \%\right)$ & 115 & 64.7 & 224.3 & $1.1-2,286.9$ & 64.8 & 9.5 & $50.4-79.2$ & 17.4 & 16.2 & 4.1 & 4.3-21.7 \\
\hline \multicolumn{12}{|l|}{ Stage } \\
\hline 1 & 48 & 10.9 & 59.0 & $1.1-343.3$ & 79.2 & 10.2 & $50.4-79.2$ & 52.1 & 9.1 & 3.8 & $2.4-17.3$ \\
\hline$\|$ & 16 & 52.2 & 62.9 & $5.7-181.3$ & 70.2 & 9.5 & $54.0-79.2$ & 25.0 & 14.4 & 9.2 & $5.0-19.6$ \\
\hline IIIA & 35 & 64.7 & 76.8 & $1.5-333.2$ & 61.2 & 7.9 & $50.4-79.2$ & 2.9 & 15.3 & 4.1 & $5.0-19.6$ \\
\hline$I I I B$ & 64 & 73.2 & 296.4 & $6.5-2,286.9$ & 61.2 & 9.2 & $50.4-79.2$ & 10.9 & 16.9 & 3.7 & $5.6-21.7$ \\
\hline Total group & 166 & 50.3 & 194.8 & $1.1-2,286.9$ & 64.8 & 9.9 & $50.4-79.2$ & 22.3 & 14.8 & 4.6 & $2.4-21.7$ \\
\hline
\end{tabular}

about all inhabitants of the Netherlands. No specific protocol was used with regard to imaging during follow-up; imaging was performed according to local guidelines or if it was clinically indicated. Acute and late toxicity were scored according to Common Terminology Criteria of Adverse Events (CTCAE) v3.0.

\section{Statistical Methods}

Considering an increase in 2-year OS of 10\% compared with that of a standard radiation schedule to be successful, the number of patients to be included was calculated to be 157 (power $=0.8$; alpha $=.05$; $00=25 \%$; $\mathrm{p} 1=35 \%)$. SPSS for Windows software (SPSS, Chicago, IL) was used for statistical analysis. OS was calculated from the start of radiotherapy. The Kaplan-Meier method was used for univariate survival analysis (log-rank test). The Cox proportional hazards model was used for multivariate analysis testing the following variables: total GTV, weight loss, $\mathrm{EQD}_{2, \mathrm{~T}}$, TTD, stage, WHO performance status, age, induction chemotherapy, sex, and lung function tests. Variables were considered statistically significant if the likelihood ratio test resulted in $P<.05$. Crude incidences of pulmonary complaints (cough and dyspnea) and esophageal dysphagia (maximum score) were calculated for the acute phase (90 days from start of radiotherapy) and for the late phase $(>90$ days from start of radiotherapy).

\section{RESULTS}

\section{Patient and Treatment Characteristics}

Between December 2004 and June 2007, 166 patients (115 males and 51 females) with a median age of $69.0 \pm 10.4$ years (range, 42 to 88 years) were enrolled. Patient and tumor characteristics are presented in Table 1 . Sixty percent of patients $(n=99)$ had stage III disease, 9.6\% $(n=16)$ had stage II, and $28.9 \%(n=48)$ had stage I. However, in the poor lung function group (group $1 ; \mathrm{n}=25$; maximum MLD $10 \mathrm{~Gy}$ ), $80 \%$ had stage I disease $(n=20)$, while this percentage was $34.6 \%$ in group 2 ( 9 of 26; maximum MLD 15 Gy) and 16.5\% in group 3 (19 of 115; maximum MLD 19 Gy). Ninety-two (55\%) patients received induction chemotherapy. The median total GTV was $50.3 \pm 194.8 \mathrm{~mL}$ (range, 1.1 to 2,286.9 $\mathrm{mL}$; Table 2). The median prescribed TTD for the total group of patients was $64.8 \pm 11.4 \mathrm{~Gy}$. TTD according to lung function groups and stage is depicted in Table 2. The median $\mathrm{EQD}_{2, \mathrm{~T}}$ was $66.0 \pm 7.1 \mathrm{~Gy}$ (range, 51.9 to 73.1 Gy). The median delivered TTD of $64.8 \pm 11.4 \mathrm{~Gy}$ (range, 5.4 to $79.2 \mathrm{~Gy}$ ) was delivered in twice daily fractions in all patients in a median overall treatment time of $25 \pm 5.8$ days (range, 2 to 50 days). The median MLD was $14.8 \pm 4.6 \mathrm{~Gy}$ (range, 2.4 to 21.7 Gy; Table 2), and in 55 (33.1\%) patients, the MLD was dose-limiting. Three patients did not complete their radiation schedule: one patient died after three fractions because of broncho- pneumonia and cardiac arrhythmia, one patient stopped after 12 fractions because the schedule was too exhausting, and one patient switched to a once-daily schedule. In four (2.4\%) patients, a major protocol violation was encountered: three patients had stage IV

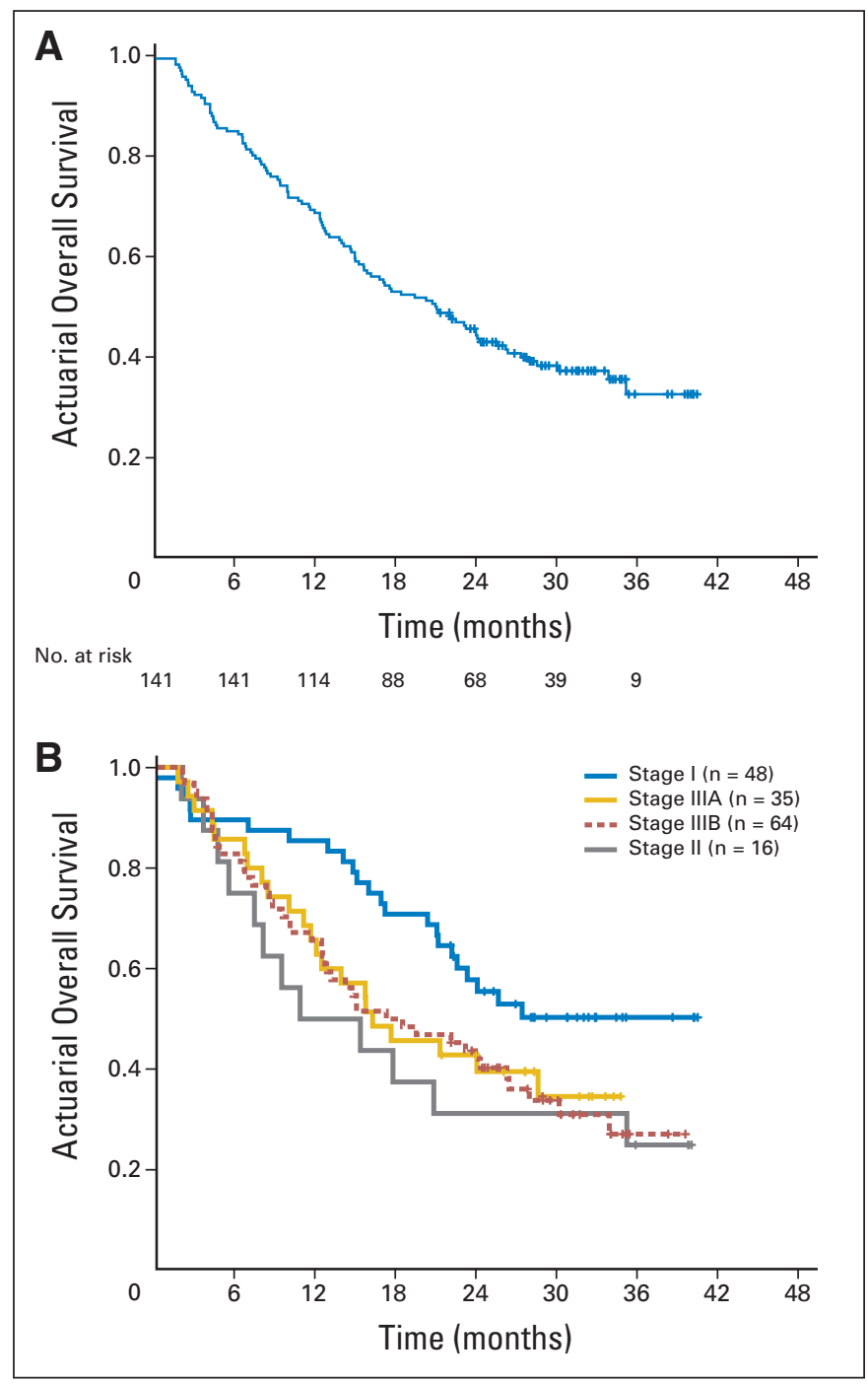

Fig 1. Actuarial overall survival in months for $(A)$ the total group of patients and (B) for different disease stages. 
disease (simultaneous solitary brain metastasis treated with resection or stereotactic radiosurgery followed by sequential chemoradiotherapy for the lung tumor) and in one patient, an MLD of 21.7 Gy was accepted to achieve a TTD of 50.4 Gy.

\section{Survival}

The median follow-up time for the total group of patients was 31.6 months (95\% CI, 29.9 to 33.4 months). Minimal follow-up was 22 months. At the time of analysis 103 (62\%) patients had died. The median OS was 21.0 months (95\% CI, 15.8 to 26.2 months) with a 1 -year OS of $68.7 \%$ and a 2 -year OS of $45.0 \%$ (Fig 1). For the different disease stages, the median OS was as follows: stage I, not reached; stage II, 10.8 months ( $95 \%$ CI, 0 to 22.3 months); stage IIIA, 16.2 months (95\% CI, 7.6 to 24.8 months); and stage IIIB, 17.2 months (95\% CI, 8.4 to 26.0 months). Seventy-five patients (45\%) had a recurrence (33\% locoregional failure, 51\% metastases, and 16\% a combination of both as first event).

\section{Univariate and Multivariate Analysis}

On univariate analysis, OS was better with a higher $\mathrm{EQD}_{2, \mathrm{~T}}$ $(P=.012)$ and a higher TTD $(P=.022)$, while patients with a large GTV showed a worse OS $(P<.001)$. A trend for a better OS was observed for early stages $(P=.052)$. All other factors investigated were not correlated with OS (Table 3). On multivariate analysis only, GTV was an independent risk factor for $\mathrm{OS}(P<.001)$. Figure 2 shows the survival curves according to GTV and TTD.

\section{Toxicity}

Acute toxicity during and directly after radiotherapy was mainly mild (Figs 3A-3C). Most patients $(\mathrm{n}=76)$ developed no $(45.8 \%)$ or mild dysphagia $(27.1 \%$, grade $1 ; 21.7 \%$, grade 2$)$, while eight patients $(4.8 \%)$ had acute grade 3 dysphagia. In all these patients, dysphagia was transient (late grade 3,0\%). Before start of radiotherapy, seven patients $(4.2 \%)$ had grade 3 and one patient $(0.6 \%)$ had grade 4 dyspnea (dyspnea at rest; the radiation oncologist and pulmonologist decided that the patient was able to undergo radical treatment, which he completed). During radiotherapy, $60.3 \%$ had mild dyspnea

\begin{tabular}{|c|c|c|}
\hline \multirow[b]{2}{*}{ Variable } & \multicolumn{2}{|c|}{ Overall Survival } \\
\hline & UVA & MVA \\
\hline GTV $\geq$ median $v$ GTV $<$ median & $<0.001$ & $<0.001$ \\
\hline No weight loss $v$ weight loss $(<10 \%)$ & 0.002 & 0.211 \\
\hline $\mathrm{EQD}_{2, \mathrm{~T}} \geq$ median $v \mathrm{EQD}_{2, \mathrm{~T}}<$ median & 0.012 & 0.298 \\
\hline TTD $\geq$ median $v$ TTD $<$ median & 0.022 & 0.224 \\
\hline Stage I-II $v$ III-IV & 0.052 & 0.859 \\
\hline WHO PS $0 v \geq 1$ & 0.204 & NA \\
\hline Age $\geq$ median $v$ age $<$ median & 0.345 & NA \\
\hline Induction chemotherapy $v$ no induction chemotherapy & 0.383 & NA \\
\hline Sex & 0.926 & NA \\
\hline $\mathrm{FEV}_{1}$ and $\mathrm{DL}_{\mathrm{CO}} \geq 50 \% \vee \mathrm{FEV}_{1}$ and/or $\mathrm{DL}_{\mathrm{CO}}<50 \%$ & 0.993 & NA \\
\hline \multicolumn{3}{|c|}{$\begin{array}{l}\text { Abbreviations: UVA, univariate analysis; MVA, multivariate analysis; GTV, } \\
\text { total gross tumor volume; } \mathrm{ED}_{2, \mathrm{~T}} \text {, equivalent dose in } 2 \mathrm{~Gy} \text { fractions corrected } \\
\text { for proliferation; TTD, total tumor dose; } \mathrm{PS} \text {, performance status; NA, not } \\
\text { analyzed; FEV }{ }_{1} \text {, forced expiratory volume in } 1 \text { second; } \mathrm{DL}_{\mathrm{CO}} \text {, diffusing capacity } \\
\text { of lungs for carbon monoxide. }\end{array}$} \\
\hline
\end{tabular}

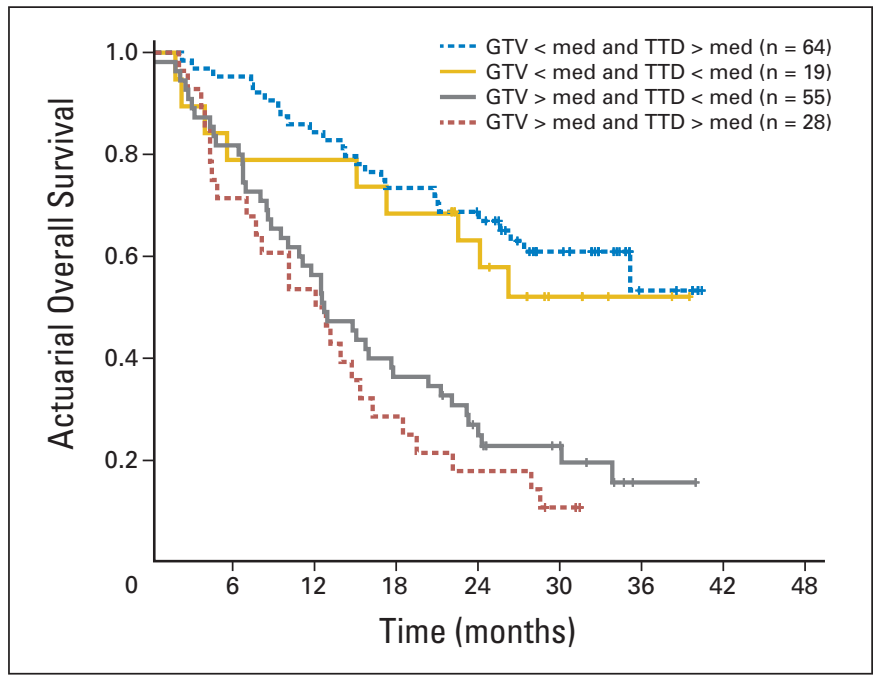

Fig 2. Actuarial overall survival in months according to gross tumor volume (GTV) and total tumor dose (TTD). med, median.

(42.2\%, grade $1 ; 18.1 \%$, grade 2$)$ while grade $3(7.8 \%)$ and grade 4 (2.4\%) dyspnea was found in $10 \%$ of patients. Grade 3 and 4 dyspnea were mainly observed in patients known to have dyspnea before start of treatment. Acute cough was observed in 131 patients (78.9\%): $51.2 \%$, grade $1 ; 15.7 \%$, grade 2 ; and $12.0 \%$, grade 3 . No severe skin reaction was observed.

Regarding late toxicity ( $>90$ days postradiotherapy), only two patients (1.2\%) had grade 1 dysphagia (Figs 3A-3C). Most patients (57.8\%) had no dyspnea, while mild dyspnea was seen in $30.1 \%$ $(21.7 \%$, grade $1 ; 8.4 \%$, grade 2$)$ and grade $3(3.0 \%)$ and grade $4(1.8 \%)$ dyspnea in $5 \%$. Grade 3 cough was observed in only one $(0.6 \%)$ patient, while 91 patients had mild cough $(50 \%$, grade $1 ; 4.8 \%$, grade 2). No myelitis was observed.

\section{DISCUSSION}

Generally, patients with NSCLC receive a predefined radiation dose that is the same for all patients with a certain tumor stage. The typical radiotherapy strategy for stage III patients-60 to 66 Gy in 2 Gy fractions once daily for 6 weeks - was established in the 1980 s. $^{32}$ This obviously does not take into account the wide diversity in patients with regard to tumor size, localization, and doselimiting normal tissues. The importance of both dose-response $\mathrm{e}^{29,33}$ and overall treatment time ${ }^{4}$ has been demonstrated for local tumor control. Therefore, this standard strategy will lead to underdosage in individuals who can tolerate higher radiation doses without undue toxicity, whereas for others, this fixed radiation dose cannot be prescribed. Since quantitative relationships between dosevolume parameters and toxicity have been established, ${ }^{34-40}$ an individualized approach delivering the highest dose with the same toxicity level, emerged. ${ }^{41}$ At the same time, radiation treatment acceleration would be a logical step, considering the high timedependency for the outcome of radiotherapy. ${ }^{4,18}$

We previously investigated this hypothesis in a modeling study, estimating a gain in tumor control probability of approximately $25 \%$ 


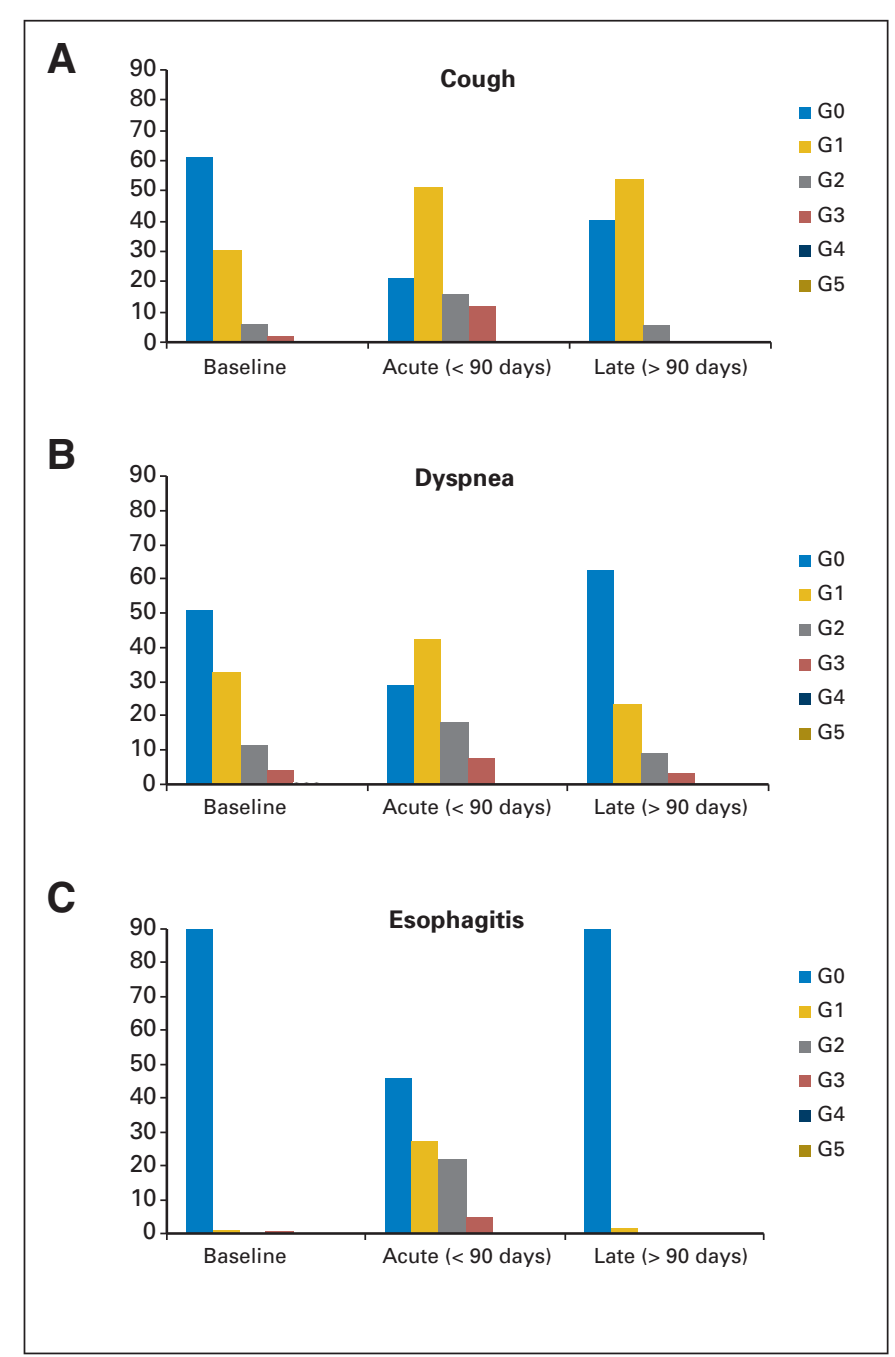

Fig 3. Percentage of patients with toxicity. Scoring according to Common Terminology Criteria of Adverse Events version 3.0 for baseline, acute toxicity within 90 days, and late toxicity after 90 days for (A) cough, (B) dyspnea, and (C) esophagitis. G, grade.

compared with the classical scheme of $60 \mathrm{~Gy} .{ }^{16}$ Subsequently, in a feasibility study $(\mathrm{n}=28)$, we showed the safety of this approach. ${ }^{17}$ This study evaluated the mature results of a prospective study that used an individualized dose prescription. The $\mathrm{EQD}_{2, \mathrm{~T}}(\geq 54 \mathrm{~Gy}$ ) for all patients was higher than the $\mathrm{EQD}_{2, \mathrm{~T}}$ equivalent for a classic scheme of 60 Gy in 2 Gy fractions once daily.

The median OS of 21 months for the total group was high, although rather low for stage II (median OS, 10.8 months; not significantly different compared with that for stage IIIA). This might be partially explained by the low number of patients $(n=16)$ and the high incidence of comorbidity in this group. In addition, according to guidelines, stage II patients did not receive induction chemotherapy as those with stage III would have. ${ }^{42}$ However, the main factor for OS is tumor volume, and no difference in GTV was observed for stages II and IIIA $(52.2 \mathrm{~mL}$ and $64.7 \mathrm{~mL}$, respectively; $P=$ not significant). Median OS for stage III patients was high at 17 months. These results are in line with the results of our feasibility study ${ }^{17}$ and those of other dose-escalation studies. Adkison et $\mathrm{al}^{43}$ reported similar findings in a phase I study that used a hypofrac- tionated schedule with helical tomotherapy IMRT up to a maximal dose of 80.5 Gy. With a relatively short median follow-up of 8.1 months, they observed limited toxicity, a median survival of 18 months, and a 2 -year OS of $46.8 \%$. Recently, the results of a phase II trial combining induction chemotherapy with continuous hyperfractionated accelerated radiotherapy (CHART) in locally advanced NSCLC have been published, ${ }^{44}$ in which 56 Gy was delivered in 36 fractions in 12 days; toxicity was mild, and the median OS was 15.7 months. Compared with other doseescalation trials, we achieved good results in a group of patients with rather large tumors (median GTV, $50.3 \mathrm{~mL} v 47.3 \mathrm{~mL}$ in the Radiation Therapy Oncology Group trial), even when including individuals with an $\mathrm{FEV}_{1}$ and/or $\mathrm{DL}_{\mathrm{CO}}$ as low as $30 \%$ and patients older than age 80 years. ${ }^{7,9,43,45}$

Our results as well as those of other dose-escalation studies suggest that $O S$ rates could be achieved with sequential chemotherapy and high-dose radiation schedules that come close to the results of concurrent chemoradiation schemes but with less acute toxicity. ${ }^{46-52}$ Because the superior results of concurrent chemoradiotherapy over the sequential approach are probably due to improved local control, ${ }^{6}$ we hypothesize that high-dose radiotherapy in sequential protocols might lead to similar local control rates. However, one of the drawbacks of this study is that local progression data should be interpreted with caution, since CT imaging was performed only if clinically indicated. Moreover, this was a singlearm, prospective study in a relatively heterogeneous group of patients and therefore should be followed by a prospective randomized study.

In our multivariate analysis, only size of GTV was an independent risk factor for death. Werner-Wasik et $\mathrm{al}^{45}$ also showed in the Radiation Therapy Oncology Group 93-11 trial that an increasing GTV was strongly associated with a decreased median survival, whereas maximal radiation dose was not a significant factor. This might be explained by the fact that the spread in TTD was still limited and that higher doses are needed. It might also indicate that, especially for larger tumors, tumoricidal dose cannot be reached applying the studied protocol. Therefore other strategies, such as individualized dose prescription in concurrent chemoradiation and/or boosting certain parts of the tumor, need to be investigated.

As in other dose-escalation studies ${ }^{7,38}$ and as predicted in our modeling study, ${ }^{16}$ toxicity was generally mild. Severe esophagitis was observed in less than $5 \%$ of patients and was transient in all. Severe pulmonary symptoms were observed in approximately $10 \%$ of patients during treatment, mainly patients with pre-existing symptoms due to other lung diseases. Pulmonary symptoms did not increase during radiotherapy in the majority of patients. Even more assuring is that no late esophageal or spinal cord damage was observed. Only one patient had severe late pulmonary toxicity, but this particular patient already had grade 4 dyspnea before start of treatment. The currently available dose-volume relations for toxicity, although not perfect, ${ }^{34-40}$ are apparently good enough to enable individualized radiation dose prescription.

Our strategy to prescribe the radiation dose based on individualized dose constraints is safe and feasible in daily practice and shows promising results. Further improvements are ongoing, including a recently closed prospective study in our department that investigated individualized dose prescription in concurrent chemoradiation and image-guidance as well as IMRT techniques. ${ }^{11,43,53}$ The 
addition of active breathing control might potentially give the opportunity to further dose escalation, while respecting normal tissue dose constraints. ${ }^{54}$ In the future, further individualization of treatment might incorporate patient-specific factors, such as comorbidity, ${ }^{39,40}$ as well as biologic tumor characteristics, such as hypoxia, growth factors, and cytokines, ${ }^{55,56}$ along with imaging data to individualize margins and to refine the dose constraints beyond physical dose-volume parameters and simple patient characteristics as were used in this trial.

In conclusion, in line with our modeling and feasibility study, we showed that individualized prescribed radical radiotherapy in NSCLC based on normal tissue dose constraints has promising results. Furthermore, such a regimen can be applied safely, with acceptable acute and late toxicity. These results may be the basis for a prospective randomized trial that ultimately could demonstrate the superiority of this individualized approach.

\section{AUTHORS' DISCLOSURES OF POTENTIAL CONFLICTS} OF INTEREST

The author(s) indicated no potential conflicts of interest.

\section{AUTHOR CONTRIBUTIONS}

Conception and design: Angela van Baardwijk, Stofferinus Wanders, Liesbeth Boersma, Jacques Borger, Michel Öllers, Philippe Lambin, Dirk De Ruysscher

Provision of study materials or patients: Angela van Baardwijk, Stofferinus Wanders, Liesbeth Boersma, Jacques Borger, Michel Öllers, Anne-Marie C. Dingemans, Gerben Bootsma, Wiel Geraedts, Cordula Pitz, Ragnar Lunde, Dirk De Ruysscher

Collection and assembly of data: Angela van Baardwijk, Stofferinus Wanders, Liesbeth Boersma, Jacques Borger, Michel Öllers, Anne-Marie C. Dingemans, Gerben Bootsma, Wiel Geraedts, Cordula Pitz, Ragnar Lunde, Dirk De Ruysscher

Data analysis and interpretation: Angela van Baardwijk, Philippe Lambin, Dirk De Ruysscher

Manuscript writing: Angela van Baardwijk, Stofferinus Wanders, Liesbeth Boersma, Jacques Borger, Michel Öllers, Anne-Marie C. Dingemans, Gerben Bootsma, Wiel Geraedts, Cordula Pitz, Ragnar Lunde, Philippe Lambin, Dirk De Ruysscher

Final approval of manuscript: Angela van Baardwijk, Stofferinus Wanders, Liesbeth Boersma, Jacques Borger, Michel Öllers, Anne-Marie C. Dingemans, Gerben Bootsma, Wiel Geraedts, Cordula Pitz, Ragnar Lunde, Philippe Lambin, Dirk De Ruysscher

\section{REFERENCES}

1. Ferlay J, Autier P, Boniol M, et al: Estimates of the cancer incidence and mortality in Europe in 2006. Ann Oncol 18:581-592, 2007

2. Moreno-Jiménez M, Aristu J, Lopez-Picazo $\mathrm{JM}$, et al: Dosimetric analysis of the patterns of local failure observed in patients with locally advanced non-small cell lung cancer treated with neoadjuvant chemotherapy and concurrent conformal (3D-CRT) chemoradiation. Radiother Oncol 88:342-350, 2008

3. Le Chevalier T, Arriagada R, Quoix E, et al: Radiotherapy alone versus combined chemotherapy and radiotherapy in nonresectable non-small-cell lung cancer: First analysis of a randomized trial in 353 patients. J Natl Cancer Inst 83:417-423, 1991

4. Saunders $M$, Dische $S$, Barrett $A$, et al: Continuous, hyperfractionated, accelerated radiotherapy (CHART) versus conventional radiotherapy in nonsmall cell lung cancer: Mature data from the randomised multicentre trial-CHART Steering Committee. Radiother Oncol 52:137-148, 1999

5. Aupérin A, Le Pechoux C, Pignon JP, et al: Concomitant radio-chemotherapy based on platin compounds in patients with locally advanced nonsmall cell lung cancer (NSCLC): A meta-analysis of individual data from 1764 patients. Ann Oncol 17: 473-483, 2006

6. Auperin A, Rolland E, Curran W, et al: Concomitant radio-chemotherapy (RT-CT) versus sequential RT-CT in locally advanced non-small cell lung cancer (NSCLC): A meta-analysis using individual patient data (IPD) from randomised clinical trials (RCTs). J Thorac Oncol 2:S310, 2007 (suppl 4) WCLC Seoul, Korea, 2007

7. Belderbos JS, Heemsbergen WD, De Jaeger $K$, et al: Final results of a Phase $1 /$ II dose escalation trial in non-small-cell lung cancer using threedimensional conformal radiotherapy. Int $\mathrm{J}$ Radiat Oncol Biol Phys 66:126-134, 2006

8. De Ruysscher D, Wanders R, van Haren E, et al: HI-CHART: A phase I/II study on the feasibility of high-dose continuous hyperfractionated accelerated radiotherapy in patients with inoperable non-small- cell lung cancer. Int J Radiat Oncol Biol Phys 71:132138, 2008

9. Kong FM, Ten Haken RK, Schipper MJ, et al: High-dose radiation improved local tumor control and overall survival in patients with inoperable/unresectable non-small-cell lung cancer: Long-term results of a radiation dose escalation study. Int $J$ Radiat Oncol Biol Phys 63:324-333, 2005

10. Rowell NP, O'Rourke NP: Concurrent chemoradiotherapy in non-small cell lung cancer. Cochrane Database Syst Rev 4:CD002140, 2004

11. Haasbeek CJ, Slotman BJ, Senan S: Radiotherapy for lung cancer: Clinical impact of recent technical advances. Lung Cancer 64:1-8, 2009

12. Nestle U, Kremp S, Grosu AL: Practical integration of [18F]-FDG-PET and PET-CT in the planning of radiotherapy for non-small cell lung cancer (NSCLC): The technical basis, ICRU-target volumes, problems, perspectives. Radiother Oncol 81:209225, 2006

13. van Baardwijk $A$, Baumert BG, Bosmans $G$, et al: The current status of FDG-PET in tumour volume definition in radiotherapy treatment planning. Cancer Treat Rev 32:245-260, 2006

14. van Meerbeeck JP, Meersschout S, De Pauw $\mathrm{R}$, et al: Modern radiotherapy as part of combined modality treatment in locally advanced non-small cell lung cancer: Present status and future prospects. Oncologist 13:700-708, 2008

15. Fenwick JD, Nahum AE, Malik ZI, et al: Escalation and intensification of radiotherapy for stage III non-small cell lung cancer: Opportunities for treatment improvement. Clin Oncol (R Coll Radiol) 21: 343-360, 2009

16. van Baardwijk A, Bosmans G, Bentzen SM, et al: Radiation dose prescription for non-small-cell lung cancer according to normal tissue dose constraints: An in silico clinical trial. Int $\mathrm{J}$ Radiat Oncol Biol Phys 71:1103-1110, 2008

17. van Baardwijk A, Bosmans G, Boersma L, et al: Individualized radical radiotherapy of non-smallcell lung cancer based on normal tissue dose constraints: A feasibility study. Int J Radiat Oncol Biol Phys 71:1394-1401, 2008
18. Baumann $M$, Herrmann $T$, Koch $R$, et al: Continuous hyperfractionated accelerated radiotherapyweekend less (CHARTWEL) versus conventionally fractionated (CF) radiotherapy in non-small-cell lung cancer (NSCLC): First results of a phase III randomised multicentre trial (ARO 9-71) ECCO 13, 2005. Eur J Cancer Supplements 3:322, 2005

19. Landelijke Werkgroep Longtumoren. Nietkleincellig longcarcinoom, landelijke richtlijn (version 1.3). VIKC, 2004

20. Senan S, De Ruysscher D, Giraud $P$, et al: Literature-based recommendations for treatment planning and execution in high-dose radiotherapy for lung cancer. Radiother Oncol 71:139-146, 2004

21. International Commission on Radiation Units: Prescribing, Recording, and Reporting Photon Beam Therapy. Washington, DC, International Commission on Radiation Units and Measurements, ICRU Report 50, 1993

22. Nijsten SM, Mijnheer BJ, Dekker $A L$, et al: Routine individualised patient dosimetry using electronic portal imaging devices. Radiother Oncol 83: 65-75, 2007

23. Schultheiss TE, Kun LE, Ang KK, et al: Radiation response of the central nervous system. Int J Radiat Oncol Biol Phys 31:1093-1112, 1995

24. Kelsey CR, Kahn D, Hollis DR, et al: Radiationinduced narrowing of the tracheobronchial tree: An in-depth analysis. Lung Cancer 52:111-116, 2006

25. Maguire PD, Marks LB, Sibley GS, et al: 73.6 Gy and beyond: Hyperfractionated, accelerated radiotherapy for non-small-cell lung cancer. J Clin Oncol 19:705-711, 2001

26. Marks LB, Garst J, Socinski MA, et al: Carboplatin/paclitaxel or carboplatin/vinorelbine followed by accelerated hyperfractionated conformal radiation therapy: Report of a prospective phase I dose escalation trial from the Carolina Conformal Therapy Consortium. J Clin Oncol 22:4329-4340, 2004

27. Fowler JF, Bentzen SM, Bond SJ, et al: Clinical radiation doses for spinal cord: The 1998 international questionnaire. Radiother Oncol 55:295-300, 2000

28. Belderbos J, Heemsbergen W, Hoogeman M, et al: Acute esophageal toxicity in non-small cell lung 
cancer patients after high dose conformal radiotherapy. Radiother Oncol 75:157-164, 2005

29. Fowler JF, Tome WA, Fenwick JD, et al: A challenge to traditional radiation oncology. Int $J$ Radiat Oncol Biol Phys 60:1241-1256, 2004

30. Bentzen SM, Saunders MI, Dische S: From CHART to CHARTWEL in non-small cell lung cancer: Clinical radiobiological modelling of the expected change in outcome. Clin Oncol (R Coll Radiol) 14: 372-381, 2002

31. Steel G: Basic Clinical Radiobiology (ed 3). London, United Kingdom: Hodder Arnold Publications, 2002

32. Perez CA, Stanley K, Rubin P, et al: A prospective randomized study of various irradiation doses and fractionation schedules in the treatment of inoperable non-oat-cell carcinoma of the lung. Preliminary report by the Radiation Therapy Oncology Group. Cancer 45:2744-2753, 1980

33. Timmerman RD, Park C, Kavanagh BD: The North American experience with stereotactic body radiation therapy in non-small cell lung cancer. J Thorac Oncol 2:S101-S112, 2007

34. Kwa SL, Lebesque JV, Theuws JC, et al: Radiation pneumonitis as a function of mean lung dose: An analysis of pooled data of 540 patients. Int J Radiat Oncol Biol Phys 42:1-9, 1998

35. Rodrigues G, Lock M, D'Souza D, et al: Prediction of radiation pneumonitis by dose-volume histogram parameters in lung cancer: A systematic review. Radiother Oncol 71:127-138, 2004

36. Bradley JD, Hope A, El Naqa I, et al: A nomogram to predict radiation pneumonitis, derived from a combined analysis of RTOG 9311 and institutional data. Int J Radiat Oncol Biol Phys 69:985992, 2007

37. Kocak Z, Borst GR, Zeng J, et al: Prospective assessment of dosimetric/physiologic-based models for predicting radiation pneumonitis. Int J Radiat Oncol Biol Phys 67:178-186, 2007

38. Kong FM, Hayman JA, Griffith KA, et al: Final toxicity results of a radiation-dose escalation study in patients with non-small-cell lung cancer (NSCLC): Predictors for radiation pneumonitis and fibrosis. Int J Radiat Oncol Biol Phys 65:1075-1086, 2006
39. Jin $\mathrm{H}$, Tucker $\mathrm{SL}$, Liu HH, et al: Dose-volume thresholds and smoking status for the risk of treatment-related pneumonitis in inoperable nonsmall cell lung cancer treated with definitive radiotherapy. Radiother Oncol 91:427-432, 2009

40. Dehing-Oberije C, Ruysscher DD, Baardwijk $A$, et al: The importance of patient characteristics for the prediction of radiation-induced lung toxicity. Radiother Oncol 91:421-426, 2009

41. Lawrence TS, Tesser RJ, ten Haken RK: An application of dose volume histograms to the treatment of intrahepatic malignancies with radiation therapy. Int J Radiat Oncol Biol Phys 19:1041-1047, 1990

42. Scott WJ, Howington J, Feigenberg $S$, et al: Treatment of non-small cell lung cancer stage I and stage II: ACCP evidence-based clinical practice guidelines (2nd edition). Chest 132:234S-242S, 2007

43. Adkison JB, Khuntia D, Bentzen SM, et al: Dose escalated, hypofractionated radiotherapy using helical tomotherapy for inoperable non-small cell lung cancer: Preliminary results of a risk-stratified phase I dose escalation study. Technol Cancer Res Treat 7:441-447, 2008

44. Jenkins $P$, Anderson $S$, Wronski $S$, et al: A phase II trial of induction chemotherapy followed by continuous hyperfractionated accelerated radiotherapy in locally advanced non-small-cell lung cancer. Radiother Oncol 93:396-401, 2009

45. Werner-Wasik M, Swann RS, Bradley J, et al: Increasing tumor volume is predictive of poor overal and progression-free survival: Secondary analysis of the Radiation Therapy Oncology Group 93-11 phase I-II radiation dose-escalation study in patients with inoperable non-small-cell lung cancer. Int J Radiat Oncol Biol Phys 70:385-390, 2008

46. Curran WJ Jr: Evolving chemoradiation treatment strategies for locally advanced non-small-cell lung cancer. Oncology (Williston Park) 17:7-14, 2003

47. Groen HJ, van der Leest $A H$, Fokkema $E$, et al: Continuously infused carboplatin used as radiosensitizer in locally unresectable non-small-cell lung cancer: A multicenter phase III study. Ann Oncol 15:427-432, 2004

48. Huber RM, Flentje $M$, Schmidt $M$, et al: Simultaneous chemoradiotherapy compared with radiotherapy alone after induction chemotherapy in inoperable stage IIIA or IIIB non-small-cell lung cancer: Study CTRT99/97 by the Bronchial Carcinoma Therapy Group. J Clin Oncol 24:4397-4404, 2006

49. Fournel P, Robinet G, Thomas P, et al: Randomized phase III trial of sequential chemoradiotherapy compared with concurrent chemoradiotherapy in locally advanced non-small-cell lung cancer: Groupe Lyon-Saint-Etienne d'Oncologie ThoraciqueGroupe Francais de Pneumo-Cancerologie NPC 95-01 Study. J Clin Oncol 23:5910-5917, 2005

50. Zatloukal P, Petruzelka L, Zemanova M, et al: Concurrent versus sequential chemoradiotherapy with cisplatin and vinorelbine in locally advanced non-small cell lung cancer: A randomized study. Lung Cancer 46:87-98, 2004

51. Furuse K, Kubota K, Kawahara M, et al: Phase II study of concurrent radiotherapy and chemotherapy for unresectable stage III non-small-cell lung cancer. Southern Osaka Lung Cancer Study Group. J Clin Oncol 13:869-875, 1995

52. Kubota K, Tamura T, Fukuoka M, et al: Phase II study of concurrent chemotherapy and radiotherapy for unresectable stage III non-small-cell lung cancer: Long-term follow-up results. Japan Clinical Oncology Group Protocol 8902. Ann Oncol 11:445450, 2000

53. Feng $M$, Kong FM, Gross $M$, et al: Using fluorodeoxyglucose positron emission tomography to assess tumor volume during radiotherapy for non-small-cell lung cancer and its potential impact on adaptive dose escalation and normal tissue sparing. Int J Radiat Oncol Biol Phys 73:1228-1234, 2009

54. Partridge M, Tree A, Brock J, et al: Improvement in tumour control probability with active breathing control and dose escalation: A modelling study. Radiother Oncol 91:325-329, 2009

55. Kong FM, Ao X, Wang $L$, et al: The use of blood biomarkers to predict radiation lung toxicity: A potential strategy to individualize thoracic radiation therapy. Cancer Control 15:140-150, 2008

56. Starmans MH, Krishnapuram B, Steck $H$, et al: Robust prognostic value of a knowledge-based proliferation signature across large patient microarray studies spanning different cancer types. Br J Cancer 99:1884-1890, 2008 